\title{
PENINGKATAN KUALITAS PEMBELAJARAN MELALUI PENDEKATAN PENGELOLAAN KELAS
}

\author{
Anton dan Usman \\ Fakultas Agama Islam Universitas Muhammadiyah Kupang \\ antonbima67@gmail.com and usman01@gmail.com
}

\begin{abstract}
Abstrak
Peningkatan mutu pendidikan akan tercapai apabila proses belajar mengajar yang diselenggarakan di kelas benar-benar efektif dan berguna untuk mencapai kemampuan pengetahuan, sikap dan keterampilan yang diharapkan. Karenapadadasarnya proses belajar mengajar merupakan inti dari proses pendidikan secara keseluruhan, di antaranya guru merupakan salah satufaktor yang penting dalam menentukan berhasilnya proses pembelajaran di dalam kelas. Oleh karena itu guru dituntut untuk meningkatkan peran dan kompetensinya. Guru yang kompeten akan lebih mampu menciptakan lingkungan belajar yang efektif dan akan lebih mampumengelola kelasnya sehingga hasil belajar peserta didik berada pada tingkat yang optimal. Dalam kegiatan belajar mengajar terdapat dua hal yang turut menentukan berhasil tidaknya suatu proses belajar mengajar, yaitu pengelolaan kelas dan pengajaran itu sendiri. Kedua hal itu saling tergantung. Keberhasilan pengajaran, dalam arti tercapainya tujuan-tujuan intruksional sangat bergantung pada kemampuan mengelola kelas. Kelas yang baik dapat menciptakan situasi yang memungkinkan siswa belajar sehingga merupakan titik awal keberhasilan pengajaran.
\end{abstract}

Kata Kunci: Kualitas Belajar Dan Pengelolaan Kelas

\section{Pendahuluan}

S

umberdaya manusia Indonesia yang berkualitas merupakan asset bangsa dan Negara dalam melaksanakan pembangunan nasional di berbagai sector dan dalam menghadapi tantangan kehidupan masyarakat dalam era globalisasi. Sumberdaya manusia ini tiada lain ditentukan oleh hasil produktivitas lembaga-lembaga penyelenggara pendidikan, yang terdiri atas jalur sekolah dan luar sekolah, serta secara spesifik merupakan hasil proses belajar-mengajar di kelas. Pendidikan jalur sekolah terdiri atas tiga jenjang yaitu pendidikan dasar, pendidikan menengah, dan pendidikan tinggi serta bersifat formal, karena dilaksanakan secara berkesinambungan dan adanya saling keterkaitan dalam kurikulum yang diajarkan. Jenjang pendidikan yang lebih tinggi baru bias diikuti apabila jenjang sebelumnya telah selesai diikuti dan berhasil. ${ }^{1}$ Dalam kegiatan belajar mengajar terdapat dua hal yang turut menentukan berhasil tidaknya suatu proses belajar mengajar, yaitu pengelolaan kelas dan pengajaran itu sendiri. Kedua hal itu saling tergantung. Keberhasilan pengajaran, dalam arti tercapainya

\footnotetext{
${ }^{1}$ https://akhmadsudrajat.files.wordpress.com/2012/10/pengelolaan-kelas.pdf
} 
tujuan-tujuan intruksional sangat bergantung pada kemampuan mengelola kelas. Kelas yang baik dapat menciptakan situasi yang memungkinkan siswa belajar sehingga merupakan titik awal keberhasilan pengajaran ${ }^{2}$.

Peningkatan mutu pendidikan akan tercapaia pabila proses pembelajaran yang diselenggarakan di kelasbenar-benar efektif dan berguna untuk mencapai kemampuan pengetahuan, sikap dan keterampilan yang diharapkan. Karena pada dasarnya proses pembelajaran merupakan inti dari proses pendidikan secara keseluruhan, di antaranya guru merupakan salah satu faktor yang penting dalam menentukan berhasilnya proses belajar mengajar di dalam kelas. Oleh karena itu guru dituntut untuk meningkatkan peran dan kompetensinya. Guru yang kompeten akan lebih mampu menciptakan lingkungan belajar yang efektif dan akan lebih mampu mengelola kelasnya sehingga hasil belajar peserta didik berada pada tingkat yang optimal. Adam dan Decey mengemukakan peranan guru dalam proses belajar mengajara dalah sebagaiberikut: (a) guru sebagai demonstrator, (b) guru sebagai pengelola kelas, (c) guru sebagai mediator dan fasilitator serta (d) guru sebagai evaluator. ${ }^{3}$ Apabila pengaturan kondisi belajar maksimal dengan sendirinya, besar kemungkinan proses pembelajaran akan berlangsung secara maksimal pula. Sebaliknya, apabila terdapat kekurangan antara tugas dan sarana atau alat, atau terputusnya antara satu keinginan dengan keinginan lain, atau kebutuhan dengan pemenuhannya, maka terjadilah gangguan terhadap proses belajar yang dimaksud. Gangguan dapat bersifat sementara dan ringan dan dapat pula bersifat serius dan terus menerus. Gangguan yang pertama mempersyaratkan ketrampilan mendisiplin untuk mengembalikan iklim belajar yang serasi, sedangkan gangguan yang kedua menuntut keterampilan melakukan tindakan rasional remedial. ${ }^{4}$

\section{Hakikat Pengelolaan Kelas}

Suharsimi Arikunto adalah pengelolaan kelas adalah suatu usaha yang dilakukan oleh penanggung jawab kegiatan belajar mengajar dengan maksud agar dicapai kondisi yang optimal sehingga dapat terlaksana kegiatan belajar mengajar seperti yang diharapkan. ${ }^{5}$ Sedangkan menurut Pengelolaan kelas menurut made Made Pidarta yang dikutip Ahyar mengatakan bahwa pengelolaan kelas adalah proses seleksi dan menggunakan alat-alat yang tepat terhadap problem dan situasi pengelolaan kelas. Guru bertugas menciptakan, memperbaiki, dan memelihara

\footnotetext{
${ }^{2}$ Semiawan, Conny dkk, Pendekatan Ketrampilan Proses (Jakarta: Grasindo, 1986), 63.

${ }^{3}$ Usman, Moh. Uzer, Menjadi Guru Professional (Bandung :RemajaRosdaKarya, 2002), 14.

${ }^{4}$ Suparno dkk., Dimensi-Dimensi Mengajar. Bandung: CV. Sinar Baru, 1998), 74

${ }^{5}$ Arikunto, Suharsimi, Pengelolaan Kelas dan Siswa; Sebuah Pendekatan Evaluatif (Jakarta: CV. Rajawali,1986), 143,
} 
organisasi kelas sehingga individu dapat memanfaaatkan kemampuannya, bakatnya, dan energinya pada tugas-tugas individual. ${ }^{6}$

Pengelolaan kelas termasuk upaya yang dilakukan oleh guru dalam menciptakan dan mempertahankan serta mengembang tumbuhkan motivasi belajar untuk mencapai tujuan yang telah di tetapkan". Sedangkan menurut Usman bahwa "Pengelolaan kelas yang efektif merupakan prasyarat mutlak bagi terjadinya proses belajar mengajar yang efektif". Pengelolaan dipandang sebagai salah satu aspek penyelenggaraan sistem pembelajaran yang mendasar, di antara sekian macam tugas guru di dalam kelas. Berbagai definisi tentang pengelolaan kelas yang dapat diterima oleh para ahli pendidikan, yaitu :Pengelolaan kelas didefinisikan sebagai: a) Perangkat kegiatan guru untuk mengembangkan tingkahlaku peserta didik yang diinginkan dan mengurangkan tingkah laku yang tidak diinginkan. b) Seperangkat kegiatan guru untuk mengembangkan hubungan interpersonal yang baik dan iklim sosioemosional kelas yang positif. c) Seperangkat kegiatan guru untuk menumbuhkan dan mempertahankan organisasi kelas yang efektif. Dari semua uraian di atas dapat disimpulkan bahwa pengelolaan kelas adalah upaya yang dilakukan guru dalam mengelola anak didiknya di kelas dengan menciptakan atau mempertahankan suasana atau kondisi kelas yang mendukung program pengajaran untuk mencapai tujuan yang telah ditetapkan. $^{7}$

\section{Dasar Pengelolaan Kelas Dalam Pembelajaran}

Agar pendidik berhasil dalam mengelola anak didiknya, maka ia harus mempertimbangkan metode apa yang harus dipakainya, melihat waktu, serta kondisi yang ada. Karena hal itu akan menunjang keberhasilan dalam pengelolaan kelas. Sebagaimana hadist nabi S.A.W yang diriwayatkan oleh Ibnu Mas'ud:"Nabi S.A.W mengajari kami dengan memilih hari (waktu) yang tepat, sehingga kami tidak merasa bosan" (HR. Bukhori). Hadits ini merupakan salah satu konsep atau teori pertama yang diakui dan diadobsi oleh beberapa pakar manajemen pendidikan Islam sebagaimana diakui oleh Roestya mengatakan bahwa pengelolaan kelas yang dapat menciptakan interaksi belajar mengajar secara efektif dan efisien mempunyai dasar yang kuat dan jelas ${ }^{8}$. Pernyataan ini dapat memperjelas bahwa Islam telah mengajarkan konsep yang kuat dalam mengelolah kelas secara efektif dan efesiensi.

Penjelas hadits tersebut menyebutkan bahwa untuk menghindari rasa bosan dan jenuhnya siswa atau peserta didik dalam kelas dianjurkan kepada pendidik atau guru untuk memilih waktu yang tepat dalam proses belajar

\footnotetext{
${ }^{6}$ Pidarta, Made. Tth., Pengelolaan Kelas. Surabaya: Usaha Nasional, 1990), 47.

${ }^{7}$ Usman, Moh. Uzer. Menjadi Guru Profesional (Bandung :Remaja Rosda Karya, 2002), 14

${ }^{8}$ Roestiyah, Masalah-masalahIlmuKeguruan (Jakarta: BinaAksara, 1998), 75.
} 
mengajar dan secara khusus hadits ini mengajarkan pula kepada pengajar bahwa proses belajar mengajar yang tidak efektif dan efesiensi dapat mengakibatkan kebosanan peserta didik, oleh karena demikian, sebagai pendidik harus memiliki kreatifitas dan inovasi dalam mengelola kelas sehingga tidak siswa dapat belajar dengan tenang, nyama, didalam kelasnya. Perlu diketahui bersama dalam agama Islam jauh sebelumnyaternyata telah mengajarkan kepada pendidik untuk bisa mengelolah kelas dengan baik, mengelola kelas dengan merupakan bagian dari sunnah yang telah diajarkan oleh baginda Rasulullah Saw.

\section{Tujuan Pengelolaan Kelas Dalam Proses Pembelajaran}

Pengajaran adalah proses menyampaikan atau menanamkan pengetahuan dan keterampilan. Sebagai proses menyampaikan atau menanamkan ilmu pengetahuan, maka pengajaran memiliki tujuan yang utama yaitu penguasaan materi pelajaran. Keberhasilan suatu proses pengajaran diukur dari sejauh mana siswa dapat menguasai materi pelajaran yang disampaikan guru. Materi pelajaran itu sendiri adalah pengetahuan yang bersumber dari mata pelajaran yang diberikan di sekolah. Sedangkan mata pelajaran itu sendiri adalah pengalaman-pengalaman manusia masa lalu yang disusun secara sistematis dan logis kemudian diuraikan dalam buku-buku pelajaran dan selanjutnya isi buku itu yang harus dikuasai siswa. ${ }^{9}$ Pengelolaan kelas yang dilakukan guru bukan hanya tanpa tujuan. Karena ada tujuan itulah guru selalu berusaha mengelola kelas, walaupun kelelahan fisik maupun pikiran dirasakan. Tujuan pengelolan kelas pada hakekatnya mengandung tujuan pengajaran. Karena pengajaran merupakan salah satu faktor pendukung berhasil tidaknya proses belajar mengajar dalam kelas.

Secara umum tujuan pengelolaan kelas adalah penyediaan fasilitas bagi bermacam-macam kegiatan belajar siswa dalam lingkungan sosial, emosional dan intelektual belajar dan bekerja, terciptanya suasana sosial yang memberikan kepuasan suasana disiplin, perkembangan intelektual, emosional dan sikap, serta apresiasi pada siswa ${ }^{10}$ Adapun secara khusus, tujuan pengelolaan kelas adalah mengembangkan kemampuan siswa dalam menggunakan alat-alat belajar, menyediakan kondisi-kondisi yang memungkinkan siswa bekerja dan belajar, serta membantu siswa untuk memperoleh hasil yang diharapkan. ${ }^{11}$ Dari beberapa pengertian tujuan pengelolaan kelas di atas maka dapat diambil kesimpulan bahwa tujuan dari pengelolaan kelas adalah menciptakan dan menjaga kondisi kelas agar proses belajar mengajar dapat berlangsung dengan baik. Artinya upaya yang dilakukan oleh guru agar masing-masing siswa dengan kemampuannya yang heterogen dapat mengikuti materi yang disampaikan guru.

75.

${ }^{9}$ Sanjaya, 2005. PembelajarandanPengajaran, (Bandung: Remaja Rosda Karya, 2005),

${ }^{10}$ Sudirman, TeknikPengelolaanKelas, (Bandung: RosdaKarya, 1992), 31.

${ }^{11}$ Usman, M Uzer. Menjadi Guru Profesional. Bandung: Remaja Rosda Karya, 1994), 8. 


\section{Sifat-Sifat Pengelolaan Kelas Dalam Proses Pembelajaran}

Menurut Nurhadi upaya untuk menciptakan dan mempertahankan suasana yang diliputi oleh motivasi siswa yang tinggi dapat dilakukan secara preventif maupun secara kuratif. Maka pengelolaan kelas, apabila ditinjau dari sifatnya, dapat dibedakan menjadi dua yaitu ${ }^{12}$ :

1. Pengelolaan kelas yang bersifat preventif. Dikatakan secara preventif apabila upaya yang dilakukan atas dasar inisiatif guru untuk menciptakan suatu kondisi dari kondisi masa menjadi interaksi pendidikan dengan jalan menciptakan kondisi baru yang menguntungkan bagi proses belajar mengajar. Pengelolaan kelas yang preventif ini dapat berupa tindakan, contoh atau pemberian informasi yang dapat diberikan kepada siswa sehingga akan berkembang motivasi yang tinggi, atau agar motivasi yang sudah baik itu tidak dinodai oleh tindakan siswa yang menyimpang sehingga mengganggu proses belajar mengajar di kelas.

2. Pengelolaan kelas yang bersifat kuratif. Pengelolaan kelas secara kuratif adalah pengelolaan kelas yang dilaksanakan karena terjadi penyimpangan pada tingkah laku siswa sehingga mengganggu jalannya proses belajar mengajar. Dalam hal ini kegiatan pengelolaan kelas akan berusaha menghentikan tingkah laku yang menyimpang tersebut dan kemudian mengarahkan terciptanya tingkah laku siswa yang mendukung terselenggaranya proses belajar mengajar dengan baik. ${ }^{13}$

\section{Jenis Dan Prosedur Pengelolaan Kelas Dalam Proses Pembelajaran}

Adapun prosedur dari jenis-jenis pengelolaan kelas tersebut adalah sebagai berikut:

1. Prosedur pengelolaan kelas yang bersifat preventif. Suatu kondisi belajar yang optimal dapat tercapai jika guru mampu mengatur anak didik dan sarana pengajaran serta mengendalikannya dalam suasana yang menyenangkan untuk mencegah terjadinya penyimpangan tingkah laku dari anak didik dan mencapai tujuan pengajaran. Maka dari itu, hendaknya guru mengetahui langkah-langkah preventif (pemeliharaan kondisi belajar) dalam pengelolaan kelas. Prosedur pengelolaan kelas secara preventif akan meliputi langkahlangkah peningkatan kesadaran guru sebagai pendidik, peningkatan kesadaran siswa, penampilan sikap guru, pengenalan terhadap tingkah laku siswa, penemuan alternatif pengelolaan kelas, dan pembuatan kontrak sosial dalam proses belajar mengajar. ${ }^{14}$

${ }^{12}$ Nurhadi, Muljani A, Administrasi Pendidikan di Sekolah (Yogyakarta: IKIP, 1993), 163.

\footnotetext{
${ }^{13}$ Nurhadi, Muljani A, Administrasi Pendidikan di Sekolah...,163.

${ }^{14}$ Nurhadi, Muljani A, Administrasi Pendidikan di Sekolah...,164.
} 
2. Prosedur pengelolaan kelas yang bersifat kuratif. Adapun prosedur pengelolaan kelas secara kuratif akan meliputi langkah-langkah identifikasi masalah, analisa masalah, penetapan alternativ pemecahan masalah, monitoring dan memanfaatkan umpan balik ${ }^{15}$.

a. Identifikasi masalah

Pertama-tama seorang guru melakukan identifikasi masalah dengan jalan berusaha memahami dan menyelidiki penyimpangan tingkah laku siswa yang dapat mengganggu proses kelancaran pendidikan di kelas.Upaya penyelidikan terhadap tingkah laku dapat dalam arti apakah termasuk tingkah laku yang berdampak motif secara luas atau tidak, ataukah penyimpangan tingkah laku itu bersifat sesaat saja atau sering dilakukan, ataukah sekedar kebiasaan siswa.

b. Analisa masalah

Dengan hasil penyelidikan yang mendalam, seorang guru dapat melanjutkan pada langkah ini yaitu suatu kegiatan yang berusaha mengetahui latar balakang serta sebab-sebab timbulnya tingkah laku yang menyimpang tersebut. Dengan cara yang demikian akan dapat ditemukan sumber masalah yang sebenarnya, upaya untuk mengatasinya dapat dilakukan dengan baik. Jadi, dengan guru mengetahui tingkah laku anak didik yang menyimpang itu, maka guru dapat menganalisanya dan berusaha menemukan pemecahannya dengan menggunakan berbagai pendekatan pemecahan masalah. Misalnya, memberikan perhatian yang lebih, memberikan pengarahan atau nasehat dan lain sebagainya.

c. Penetapan alternatif pemecahan

Setelah mengetahui sumber masalahnya, seorang guru dapat mencoba mengkaji berbagai alternatif pemecahan untuk mengatasi masalah-masalah tersebut. Untuk dapat memperoleh alternatif-alternatif pemecahan itu, maka ia hendaknya mengetahui berbagai pendekatan yang dapat dipergunakan dalam pengelolaan kelas dan juga memahami caracara untuk mengatasi setiap masalah sesuai dengan pendekatan masingmasing. Dengan membandingkan berbagai alternatif pendekatan yang mungkin dapat dipergunakan, seorang guru dapat memilih alternatif yang terbaik untuk mengatasi masalah itu pada suatu situasi yang dihadapinya. Dengan terpilihnya salah satu pendekatan, maka cara-cara mengatasi masalah tersebut juga akan dapat ditetapkan. Dengan demikian pelaksanaan pengelolaan kelas yang berfungsi untuk mengatasi masalah tersebut dapat dilakukan.

\footnotetext{
${ }^{15}$ Nurhadi, Muljani A, Administrasi Pendidikan di Sekolah...,168.
} 
d. Monitoring

Setelah kegiatan mengatasi masalah pengelolaan kelas itu dilaksanakan, tidak dibiarkan saja, tetapi perlu dimonitor akibat-akibat yang terjadi karena perlakuan dalam mengatasi masalah tersebut. Hal ini diperlukan karena akibat perlakuan guru itu dapat saja mengenai sasaran, yaitu meniadakan tingkah laku siswa yang menyimpang itu, tetapi dapat pula tidak berakibat apa-apa atau bahkan mungkin menimbulkan tingkah laku menyimpang, berikutnya yang justru lebih jauh menyimpangnya. Langkah monitoring pada hakekatnya ditujukan untuk mengkaji akibatakibat yang terjadi tersebut.

e. Memanfaatkan umpan balik

Hasil dari kegiatan monitoring itu sebenarnya merupakan umpan balik terbaik guru yang sangat berharga, karena dengan ini ia dapat mengkaji kembali apakah alternatif tindakan yang telah dilakukan itu tepat atau tidak, atau masih perlu disempurnakan. Hasil monitoring itu hendaknya dimanfaatkan secara konstruktif, yaitu dengan cara mempergunakannya untuk: (1) Memperbaiki pengambilan alternatif yang pernah ditetapkan bila kelak menghadapi masalah yang sama pada situasi yang sama. (2) Dasar dalam melakukan kegiatan pengelolaan kelas berikutnya sebagai tindak lanjut dari kegiatan pengelolaan kelas yang sudah dilakukan sebelumnya. ${ }^{16}$

\section{Faktor Pendukung dan Penghambat Pengelolaan Kelas Dalam Kegiatan Pembelajaran}

\section{Faktor Pendukung Pengelolaan Kelas}

Menurut Nawawi ${ }^{17}$ faktor yang mendukung pengelolaan kelas dalam proses pembelajaran antara lain:

a. Kurikulum

Sebuah kelas tidak boleh sekedar diartikan sebagai tempat siswa berkumpul untuk mempelajari sejumlah ilmu pengetahuan. Demikian juga sebuah sekolah bukanlah sekedar sebuah gedung tempat murid mencari dan mendapatkan ilmu pengetahuan. Sekolah dan kelas diselenggarakan untuk memenuhi kebutuhan masyarakat dalam mendidik anak-anak yang tidak hanya harus didewasakan dari segi intelektualitasnya saja, akan tetapi dalam seluruh aspek kepribadiannya. Untuk itu bagi setiap tingkat dan jenis sekolah diperlukan kurikulum yang mampu memenuhi kebutuhan masyarakat yang semakin kompleks dalam perkembangannya. Kurikulum

\footnotetext{
${ }^{16}$ Nurhadi, Muljani A, Administrasi Pendidikan di Sekolah...,169-171.

${ }^{17}$ Nawawi, Hadari, Organisasi Sekolah dan Pengelolaan Kelas Sebagai Lembaga Pendidikan ( Jakarta: Gunung Agung 1998), 116.
} 
yang dipergunakan di sekolah sangat besar pengaruhnya terhadap aktifitas kelas dalam mewujudkan proses belajar mengajar yang berdaya guna bagi pembentukan pribadi siswa.

b. Gedung dan Sarana Kelas

Perencanaan dalam membangun sebuah gedung untuk sebuah sekolah berkenaan dengan jumlah dan luas setiap ruangan, letak dan dekorasinya yang harus disesuaikan dengan kurikulum yang dipergunakan. Akan tetapi karena kurikulum selalu dapat berubah sedang ruangan atau gedung bersifat permanen, maka diperlukan kreatifitas dalam mengatur pendayagunaan ruang/gedung. Sekolah yang mempergunakan kurikulum tradisional pengaturan ruangan bersifat sederhana karena kegiatan belajar mengajar diselenggarakan di kelas yang tetap untuk sejumlah murid yang sama tingkatannya. Sekolah yang mempergunakan kurikulum modern, ruangan kelas diatur menurut jenis kegiatan berdasarkan program-progam yang telah dikelompokkan secara integrated. Sedangkan sekolah yang mempergunakan kurikulum gabungan pada umumnya ruangan kelas masih diatur menurut keperluan kelompok murid sebagai suatu kesatuan menurut jenjang dan pengelompokan kelas secara permanen ${ }^{18}$.

c. Guru

Program kelas tidak akan berarti bilamana tidak diwujudkan menjadi kegiatan. Untuk itu peranan guru sangat menentukan karena kedudukannya sebagai pemimpin pendidikan diantara murid-murid dalam suatu kelas. Guru adalah seseorang yang ditugasi mengajar sepenuhnya tanpa campur tangan orang lain ${ }^{19}$ Setiap guru harus memahami fungsinya karena sangat besar pengaruhnya terhadap cara bertindak dan berbuat dalam menunaikan pekerjaan sehari-hari di kelas dan di masyarakat. Guru yang memahami kedudukan dan fungsinya sebagai pendidik profesional, selalu terdorong untuk tumbuh dan berkembang sebagai perwujudan perasaan dan sikap tidak puas terhadap pendidikan. Persiapan yang harus diikuti, sejalan dengan ilmu pengetahuan dan teknologi. ${ }^{20}$

d. Murid

Murid merupakan potensi kelas yang harus dimanfaatkan guru dalam mewujudkan proses belajar mengajar yang efektif. Murid adalah anakanak yang sedang tumbuh dan berkembang, dan secara psikologis dalam rangka mencapai tujuan pendidikannya melalui lembaga pendidikan

\footnotetext{
${ }^{18}$ Nawawi, Hadari, Organisasi Sekolah dan Pengelolaan Kelas Sebagai Lembaga Pendidikan..., 194.

${ }^{19}$ Nawawi, Hadari, Organisasi Sekolah dan Pengelolaan Kelas Sebagai Lembaga Pendidikan...,120.

${ }^{20}$ Nawawi, Hadari, Organisasi Sekolah dan Pengelolaan Kelas Sebagai Lembaga Pendidikan...,121
} 
formal, khususnya berupa sekolah. Murid sebagai unsur kelas memiliki perasaan kebersamaan yang sangat penting artinya bagi terciptanya situasi kelas yang dinamis. Setiap murid memiliki perasaan diterima (membership) terhadap kelasnya agar mampu ikut serta dalam kegiatan kelas. Perasaan diterima itu akan menentukan sikap bertanggung jawab terhadap kelas yang secara langsung berpengaruh pada pertumbuhan dan perkembangannya masing-masing. ${ }^{21}$

e. Dinamika Kelas

Kelas adalah kelompok sosial yang dinamis yang harus dipergunakan oleh setiap guru kelas untuk kepentingan murid dalam proses kependidikannya. Dinamika kelas pada dasarnya berarti kondisi kelas yang diliputi dorongan untuk aktif secara terarah yang dikembangkan melalui kreativitas dan inisiatif murid sebagai suatu kelompok. Untuk itu setiap wali atau guru kelas harus berusaha menyalurkan berbagai saran, pendapat, gagasan, keterampilan, potensi dan energi yang dimiliki murid menjadi kegiatan-kegiatan yang berguna.

Dengan demikian kelas tidak akan berlangsung secara statis, rutin dan membosankan. Kreativitas dan inisiatif yang baik perwujudannya tidak sekedar terbatas didalam kelas sendiri, tetapi mungkin pula dilaksanakan bersama kelaskelas yang lain atau oleh seluruh kelas. Setiap kelas harus dilihat dari dua segi. Pertama, kelas sebagai satu unit atau satu kesatuan utuh yang dapat mewujudkan kegiatan berdasarkan program masing-masing. Kedua, kelas merupakan unit yang menjadi bagian dari sekolah sebagai suatu organisasi kerja atau sebagai subsistem dari satu total sistem. Kedua sudut pandang itu harus sejalan dalam arti semua kegiatan kelas yang dapat ditingkatkan menjadi kegiatan sekolah harus dimanfaatkan sebaik-baiknya bagi semua murid. ${ }^{22}$

\section{Faktor Pengambat Pengelolaan Kelas}

Selain faktor pendukung tentu juga ada faktor penghambatnya. Dalam pelaksanaan pengelolaan kelas akan ditemui berbagai faktor penghambat. Hambatan tersebut bisa datang dari guru sendiri, dari peserta didik, lingkungan keluarga ataupun karena faktor fasilitas. ${ }^{23}$

a. Guru

Guru sebagai seorang pendidik, tentunya ia juga mempunyai banyak kekurangan. Kekurangan-kekurangan itu bisa menjadi penyebab

\footnotetext{
${ }^{21}$ Nawawi, Hadari, Organisasi Sekolah dan Pengelolaan Kelas Sebagai Lembaga Pendidikan...,125.

${ }^{22}$ Nawawi, Hadari, Organisasi Sekolah dan Pengelolaan Kelas Sebagai Lembaga Pendidikan....,130.

${ }^{23}$ Nawawi, Hadari, Organisasi Sekolah dan Pengelolaan Kelas Sebagai Lembaga Pendidikan....,130.
} 
terhambatnya kreativitas pada diri guru tersebut. Diantara hambatan itu ialah:

1) Tipe kepemimpinan guru. Tipe kepemimpinan guru (dalam mengelola proses belajar mengajar) yang otoriter dan kurang demokratis akan menimbulkan sikap pasif peserta didik. Sikap peserta didik ini akan merupakan sumber masalah pengelolaan kelas. Siswa hanya duduk rapi mendengarkan, dan berusaha memahami kaidah-kaidah pelajaran yang diberikan guru tanpa diberikan kesempatan untuk berinisiatif dan mengembangkan kreatifitas dan daya nalarnya. ${ }^{24}$

2) Gaya guru yang monoton. Gaya guru yang monoton akan menimbulkan kebosanan bagi peserta didik, baik berupa ucapan ketika menerangkan pelajaran ataupun tindakan. Ucapan guru dapat mempengaruhi motivasi siswa . Misalnya setiap guru menggunakan metode ceramah dalam mengajarnya, suaranya terdengar datar, lemah, dan tidak diiringi dengan gerak motorik/mimik. Hal inilah yang dapat mengakibatkan kebosanan belajar.

3) Kepribadian guru . Seorang guru yang berhasil, dituntut untuk bersifat hangat, adil, obyektif dan bersifat fleksibel sehingga terbina suasana emosional yang menyenangkan dalam proses belajar mengajar. Artinya guru menciptakan suasana akrab dengan anak didik dengan selalu menunjukkan antusias pada tugas serta pada kreativitas semua anak didik tanpa pandang bulu.

4) Pengetahuan guru. Terbatasnya pengetahuan guru terutama masalah pengelolaan dan pendekatan pengelolaan, baik yang sifatnya teoritis maupun pengalaman praktis, sudah barang tentu akan mengahambat perwujudan pengelolaan kelas dengan sebaik-baiknya. Oleh karena itu, pengetahuan guru tentang pengelolaan kelas sangat diperlukan ${ }^{25}$.

5) Pemahaman guru tentang peserta didik. Terbatasnya kesempatan guru untuk memahami tingkah laku peserta didik dan latar belakangnya dapat disebabkan karena kurangnya usaha guru untuk dengan sengaja memahami peserta didik dan latar belakangnya. Karena pengelolaan pusat belajar harus disesuaikan dengan minat, perhatian, dan bakat para siswa, maka siswa yang memahami pelajaran secara cepat, rata-rata, dan lamban memerlukan pengelolaan secara khusus menurut kemampuannya. Semua hal di atas memberi petunjuk kepada guru

\footnotetext{
${ }^{24}$ Masnur dkk., Dasar-Dasar Interaksi Belajar Mengajar Bahasa Indonesia (Bandung: Jemmars1987), 109.

${ }^{25}$ Wijaya, Cece dan Tabrani Rusyan, Kemampuan Dasar Guru dalam Proses Belajar Mengajar (Bandung: Remaja Rosda Karya, 1994), 136.
} 
bahwa dalam proses belajar mengajar diperlukan pemahaman awal tentang perbedaan siswa satu sama lain. ${ }^{26}$

b. Peserta didik

Peserta didik dalam kelas dapat dianggap sebagai seorang individu dalam suatu masyarakat kecil yaitu kelas dan sekolah. Mereka harus tahu hak-haknya sebagai bagian dari satu kesatuan masyarakat disamping mereka juga harus tahu akan kewajibannya dan keharusan menghormati hak-hak orang lain dan teman-teman sekelasnya.Kekurangsadaran peserta didik dalam memenuhi tugas dan haknya sebagai anggota suatu kelas atau suatu sekolah dapat merupakan faktor utama penyebab hambatan pengelolaan kelas. Oleh sebab itu, diperlukan kesadaran yang tinggi dari peserta didik akan hak serta kewajibannya dalam mengikuti kegiatan belajar mengajar.

c. Keluarga

Tingkah laku peserta didik di dalam kelas merupakan pencerminan keadaan keluarganya. Sikap otoriter orang tua akan tercermin dari tingkah laku peserta didik yang agresif dan apatis. Problem klasik yang dihadapi guru memang banyak berasal dari lingkungan keluarga. Kebiasaan yang kurang baik di lingkungan keluarga seperti tidak tertib, tidak patuh pada disiplin, kebebasan yang berlebihan atau terlampau terkekang merupakan latar belakang yang menyebabkan peserta didik melanggar di kelas.

d. Fasilitas

Fasilitas yang ada merupakan faktor penting upaya guru memaksimalkan programnya, fasilitas yang kurang lengkap akan menjadi kendala yang berarti bagi seorang guru dalam beraktivitas. Kendala tersebut seperti; (1) Jumlah peserta didik di dalam kelas yang sangat banyak, (2) Besar atau kecilnya suatu ruangan kelas yang tidak sebanding dengan jumlah siswa, dan (3) Keterbatasan alat penunjang mata pelajaran. $^{27}$

\section{Usaha Pengelolaan Kelas Dalam Meningkatkan Kemampuan Siswa Ditingkat Satuan Pendidikan}

Berdasarkan pengelolaan kelas yang disampaikan oleh beberapa pakar pendidikan, maka sasaran pengelolaan kelas itu bisa dibedakan menjadi dua macam yaitu pengelolaan fisik dan pengelolaan siswa. Adapun gambaran dapat diuraikan sebagaia berikut:

\footnotetext{
${ }^{26}$ Wijaya, Cece dan Tabrani Rusyan, Kemampuan Dasar Guru dalam Proses Belajar Mengajar...,136.

${ }^{27}$ Wijaya, Cece dan Tabrani Rusyan, Kemampuan Dasar Guru dalam Proses Belajar Mengajar...,152.
} 


\section{Pengelolaan Fisik}

Pengelolaan kelas fisik ini berkaitan dengan ketatalaksanaan atau pengaturan kelas yang merupakan ruangan yang dibatasi dinding. Siswa berkumpul mempelajari segala yang diberikan pengajar dengan harapan proses belajar mengajar berlangsung secara efektif dan efisien. Pengelolaan kelas yang bersifat fisik ini meliputi pengadaan pengaturan ventilasi dan tata cahaya, tempat duduk siswa, alat-alat pengajaran, penataan keindahan dan kebersihan kelas, dan lain-lain sebagai inventaris kelas. ${ }^{28}$

\section{Pengelolaan siswa.}

Pengelolaan siswa ini berkaitan dengan pemberian stimulus dalam rangka membangkitan dan mempertahankan kondisi motivasi siswa untuk sadar dan berperan aktif dan terlibat proses pendidikan dan pembelajaran di sekolah. Manifestasinya dapat berbentuk kegiatan tingkah laku, suasana yang diatur atau diciptakan guru dengan menstimulus siswa agar berperan serta aktif dengan proses pendidikan dan pembelajaran secara penuh. ${ }^{29}$ Bila kelas diberi batasan sebagai kelompok orang yang belajar bersama, yang mendapat pengajaran dari guru, maka didalamnya terdapat orang-orang yang melakukan kegiatan belajar dengan karakteristik mereka, masing-masing berbeda yang satu dengan yang lainnya. Perbedaan ini perlu guru pahami agar mudah melakukan pengelolaan dalam mengefektifkan belajar mengajar. Menurut Louis V Johnson dalam Djamarah ${ }^{30}$, untuk mengelola kelas secara efektif perlu memperhatikan hal-hal sebagai berikut:

1) Kelas adalah kelompok kerja yang diorganisasi untuk tujuan tertentu yang dilengkapi oleh tugas-tugas dan diarahkan oleh guru.

2) Dalam situasi kelas, guru bukan tutor untuk satu anak pada waktu tertentu, tapi bagi semua anak atau kelompok.

3) Kelompok mempunyai perilaku sendiri yang berbeda dengan perilakuperilaku individu. Kelompok itu mempengaruhi individu-individu dalam hal bagaimana mereka memandang dirinya masing-masing dan bagaimana belajar.

4) Kelompok kelas menyisipkan pengaruhnya pada anggota-anggota. Pengaruh yang jelek dapat dibatasi oleh usaha guru dalam membimbing mereka di kelas di kala belajar.

5) Praktik guru di kala belajar cenderung berpusat pada hubungan guru dan murid. Makin meningkat keterampilan guru mengelola kelas secara kelompok, makin puas anggota-anggota di dalam kelas.

${ }^{28}$ Djamarah, Syaiful Bahri. 1996. Strategi Belajar Mengajar, (Jakarta: Rineka Cipta.996),

\footnotetext{
${ }^{29}$ Djamarah, Syaiful Bahri. 1996. Strategi Belajar Mengajar...,237.

${ }^{30}$ Djamarah, Syaiful Bahri. 1996. Strategi Belajar Mengajar....,241.
} 
6) Struktur kelompok, pola komunikasi, dan kesatuan kelompok ditentukan olah guru dalam mengelola, baik untuk mereka yang tertarik pada sekolah maupun pada mereka yang apatis, masa bodoh atau bermusuhan.

7) Ditambahkannya lagi, bahwa organisasi kelas tidak berfungsi sebagai dasar terciptanya interaksi guru dan siswa, tetapi menambah terciptanya efektifitas, yaitu interaksi yang bersifat kelompok.

Berdasarkan uraian di atas, dapat disimpulkan, bahwa masalah yang perlu diperhatikan untuk membuat iklim kelas yang sehat dan efektif yang dapat meningkatkan kemampuan siswa adalah sebagai berikut: (1) Manajemen kelas, harus ada fasilitas untuk mengembangkan kesatuan dan bekerja sama, (2) Anggota kelompok harus diberi kesempatan berpartisipasi dalam pengambilan keputusan yang memberi efek kepada hubungan dan kondisi belajar, (3) Anggota-angota kelompok harus dibimbing dalam menyelesaikan kebimbangan, ketegangan dan perasaan tertekan, dan (4) Perlu diciptakan persahabatan dan kepercayaan yang kuat diantara siswa. Selain itu adanya keharmonisan hubungan guru dengan siswa mempunyai efek terhadap pengelolaan kelas dalam prorses pembeljaran di lingkup satuan pendidikan.

\section{Strategi Pengelolaan Kelas Dalam Meningkatkan Kemampuan Belajar Siswa Ditingkat Satuan Pendidikan}

\section{Menciptakan Suasana Atau Kondisi Kelas}

Seseorang guru harus bisa menciptakan suasana atau kondisi dari kondisi interaksi pendidikan dengan jalan menciptakan kondisi baru yang menguntungkan proses belajar mengajar sehingga siswa bersemangat dalam belajarnya. Keterampilan yang harus dimiliki guru yang berhubungan dengan penciptaan dan pemeliharaan kondisi belajar adalah sikap tanggap, membagi perhatian, dan pemusatan perhatian kelompok.

\section{Menghentikan Tingkah Laku Siswa yang Menyimpang}

Seorang guru melakukan identifikasi masalah dengan jalan berusaha memahami dan menyelidiki penyimpangan tingkah laku siswa yang mengganggu kelancaran proses belajar mengajar di kelas. Setelah itu guru memberikan teguran dan bimbingan serta pengarahan-pengarahan agar tercipta tingkah laku siswa yang mendukung kelancaran proses belajar mengajar.

\section{Menciptakan Disiplin Kelas Dalam Proses Pembelajaran}

Pembinaan disiplin kelas atau pencegahan terjadinya pelanggaran disiplin bisa dilakukan dengan cara membuat tata tertib kelas. Proses perumusan disiplin dalam kelas dapat dilakukan oleh guru dengan melibatkan siswa. Sehingga aturan-aturan kelasa yang disepakati dapat diterima dan dilaksanan oleh para siswadalam proses pembelajaran. 


\section{Menciptakan Keharmonisan Antara Guru Dengan Siswa}

Keharmonisan hubungan guru dengan siswa mempunyai efek terhadap pengelolaan kelas terutama dalam meningkatkan efektifitas belajar mengajar. Hubungan guru dan siswa dikatakan baik apabila hubungan itu memiliki sifatsifat diantaranya; adanya sikap keterbukaan guru maupun siswa saling bersikap jujur dan membuka diri antar satu dengan yang laintanggap, bilamana seseorang tahu bahwa tindakannya dinilai orang lain, saling ketergantungan antara satu dengan yang lain, kebebasan yang memperbolehkan setiap orang tumbuh dan mengembangkan keunikannya, kreatifitasnya, dan kepribadiannya, dan saling memenuhi kebutuhan sehingga tidak ada kebutuhan satu orangpun yang tidak terpenuhi. Demikianlah konsepsi dasar tentang pengelolaan kelas yang menjadi tugas guru selaku learning manajer. Guru harus mengetahui bahwa tingkah laku dan perbuatan anak didik dari waktu ke waktu selalu mengalami perubahan. Oleh karena itu, tugas guru selaku pengelola kelas untuk selalu berusaha mengkondisikan kelas agar dinamis yang mendukung proses interaksi edukatif mencapai tujuan pembelajaran. $^{31}$

\section{Penutup}

Guru adalah kunci utama untuk menciptakan kesuksesan dan keberhasilan dalam meningkatkan kualitas belajar sisw, minimal seorang guru dapat mengupayakan beberapa hal dalam mendisain iklim kelas yang sehat dan efektif yang dapat meningkatkan kemampuan siswa dengan menekan beberapa hal di antaranya:n (1) Melakukan kegiatan manajemen kelas yang optimal dalam proses pembelajaran, (2) Anggota kelompok harus diberi kesempatan berpartisipasi dalam pengambilan keputusan yang memberi efek kepada hubungan dan kondisi belajar, (3) Anggota-angota kelompok harus dibimbing dalam menyelesaikan kebimbangan, ketegangan dan perasaan tertekan dan perlu diciptakan persahabatan dan kepercayaan yang kuat diantara siswa, (4) Pengelolaan kelas yang dilakukan guru bukan hanya tanpa tujuan. Karena ada tujuan itulah guru selalu berusaha mengelola kelas, walaupun kelelahan fisik maupun pikiran dirasakan. Tujuan pengelolan kelas pada hakekatnya mengandung tujuan pengajaran. Karena pengajaran merupakan salah satu faktor pendukung berhasil tidaknya proses belajar mengajar dalam kelas

\section{DAFTAR PUSTAKA}

Arikunto, Suharsimi. Pengelolaan Kelas dan Siswa; Sebuah Pendekatan Evaluatif. Jakarta: CV. Rajawali, 1986.

${ }^{31}$ Gordon, Thomas, Guru Yang Efektif; Cara Untuk Mengatasi Kesulitan dalam Kelas, (Jakarta: Rajawali Press, 1990), 28. 
Djamarah, Syaiful Bahri. Strategi Belajar Mengajar. Jakarta : Rineka Cipta.1996. https://akhmadsudrajat.files.wordpress.com/2012/10/pengelolaan-kelas.pdf

Masnur dkk. Dasar-Dasar Interaksi Belajar Mengajar Bahasa Indonesia. Bandung: Jemmars. 1987.

Nawawi, Hadari. Organisasi Sekolah dan Pengelolaan Kelas Sebagai Lembaga Pendidikan. Jakarta: Gunung Agung, 1989.

Nawawi, Hadari. Organisasi Sekolah dan Pengelolaan Kelas Sebagai Lembaga Pendidikan. Jakarta: Gunung Agung1989.

Nurhadi, Muljani A. Administrasi Pendidikan di Sekolah. Yogyakarta: IKIP.1983.

Pidarta,Made. Pengelolaan Kelas. Surabaya: Usaha Nasional, Tth. 1990.

Roestiyah. Masalah-masalahIlmuKeguruan. Jakarta: BinaAksara, 1989.

Sanjaya, PembelajarandanPengajaran, Bandung: RemajaRosdaKarya, 2005.

Semiawan, Conny dkk. Pendekatan Ketrampilan Proses. Jakarta: Grasindo.1986.

Sudirman, TeknikPengelolaanKelas, Bandung: RosdaKarya, 1992.

Suparno dkk. Dimensi-Dimensi Mengajar. Bandung: CV. Sinar Baru.1988.

Usman, Moh. Uzer. Menjadi Guru Profesional. Bandung: Remaja Rosda Karya, 2002.

Wijaya, Cece dan Tabrani Rusyan. Kemampuan Dasar Guru dalam Proses Belajar Mengajar. Bandung: Remaja Rosda Karya.1994.

Gordon, Thomas (Ed.). Guru Yang Efektif; Cara Untuk Mengatasi Kesulitan dalam Kelas. Jakarta: Rajawali Press.1990. 